\title{
Perancangan dan Simulasi Tata Letak Pabrik Untuk Mengoptimalkan Biaya Material Handling Dengan Menggunakan Algoritma CRAFT dan Activity Relationship Chart Pada Industri Kerajinan Bambu
}

\author{
Nabila Noor Qisthani ${ }^{1}$, Ichsanny Aprilia Sitorus ${ }^{1}$, Heny Agustina Lusianti ${ }^{2}$ \\ 1) Program Studi Teknik Logistik, Fakultas Rekayasa Industri dan Desain, \\ Institut Teknologi Telkom Purwokerto \\ Jl. DI Panjaitan No.128, Purwokerto \\ Kabupaten Banyumas Jawa Tengah 53147 \\ Email: nabila@ittelkom-pwt.ac.id \\ 2) Program Studi Teknik Industri Program Master, Fakultas Teknologi Industri, \\ Universitas Islam Indonesia \\ Jl. Kaliurang Km. 14,5, Sleman, Daerah Istimewa Yogyakarta 55584 \\ Email: sitorusichsannyaprilia@gmail.com , henyagustinal@gmail.com
}

\begin{abstract}
ABSTRAK
CV. XYZ merupakan salah satu UMKM di daerah Yogyakarta yang memproduksi berbagai macam kerajinan bambu seperti kursi, meja dll. Perusahaan ingin meningkatkan keuntungan dengan menghemat biaya produksi dan mengoptimalkan jarak pengangkutan material yang berhubungan langsung dengan proses produksi. Pada penelitian yang dilakukan di CV XYZ terdapat tata letak yang kurang efisien. Hal ini ditunjukkan dengan aliran material yang tidak teratur, penyimpanan produksi material sisa dan banyaknya pergerakan material antar departemen. Jenis layout yang digunakan adalah desain layout proses, dengan tujuan meminimalkan momen pergerakan total. Algoritma yang digunakan adalah algoritma CRAFT yang membutuhkan data biaya transfer material yaitu perkalian jarak dengan frekuensi pergerakan. Selain itu metode yang digunakan adalah Activity Relationship Chart (ARC) suatu metode kualitatif yang menghubungkan departemen berdasarkan relasi aktivitas. Selain itu juga dilakukan simulasi untuk membandingkan layout existing dengan layout yang diusulkan. Berdasarkan penelitian yang telah dilakukan, tata letak metode CRAFT yang diusulkan dapat mereduksi pergerakan total perpindahan material menjadi $16,25 \%$ dan dari hasil simulasi layout usulan dengan metode CRAFT dapat memproduksi sebanyak 21 Produk Kursi dalam satu bulan.
\end{abstract}

Kata Kunci: Usaha Kecil Menengah, Algoritma CRAFT, ARC, Penanganan Material, Simulasi.

\section{ABSTRACT}

$C V . X Y Z$ is a small and medium enterprise that produces various kinds of bamboo handicrafts such as chairs, tables, etc. The company wants to increase profits by saving production costs and optimizing the distance to transport materials which are directly related to the production process. In the research conducted at CV XYZ, there is an inefficient layout. This is indicated by the irregular flow of material, storage of waste material production and the large number of material movements between departments. The type of layout used is the process layout design, with the aim of minimizing the total movement moment. The algorithm used is the CRAFT algorithm which requires material transfer cost data (multiplication of distance and frequency of movement). In addition, the method used is the Activity Relationship Chart (ARC), a qualitative method that connects departments based on activity relations. In addition, a simulation is also carried out to compare the existing layout with the proposed layout. Based on the research that has been done, the layout of the proposed CRAFT method can reduce the total movement of material movement to $16.25 \%$ and from the simulation results the proposed layout using the CRAFT method can produce as many as 21 Chair Products in one month.

Keywords: Small and Medium Enterprise, Algorithm CRAFT, ARC, Material Handling, Simulation. 


\section{Pendahuluan}

Tata letak fasilitas produksi merupakan masalah yang sering terjadi di dunia industri. Tata letak fasilitas merupakan salah satu hal penting untuk meningkatkan produktivitas dan berdampak signifikan terhadap kinerja perusahaan seperti biaya, kinerja pengiriman, penjadwalan produksi yang efektif dan ketepatan waktu antara permintaan satu sama lain. Secara umum tata letak fasilitas pabrik yang direncanakan baik akan sangat menentukan efisiensi serta kelangsungan hidup perusahaan (Purnomo, 2004). Perencanaan dan tata letak fasilitas sangat penting dalam proses manufaktur karena efeknya akan menyebabkan aliran produk yang efisien. Diperkirakan bahwa antara 20\%-50\% dari total biaya manufaktur terkait dengan penanganan material, biaya ini dapat dikurangi hingga hampir $70 \%$ melalui efektivitas prosedur perencanaan fasilitas (Savsar \& Aldehaim, 2020). Tata letak fasilitas yang baik yang dapat menangani sistem penanganan material secara keseluruhan (Wignjosoenroto, S., 1996). Hal ini sulit ditemukan di CV.XYZ karena sebagian besar fasilitas dan penataan tata letak pabrik masih perlu dilakukan perbaikan. CV. XYZ merupakan salah satu perusahaan yang memproduksi berbagai macam kerajinan bambu seperti seperangkat meja makan dan kursi makan, meja kursi, sekat ruangan, dan lain-lain. Perusahaan ingin meningkatkan keuntungan dengan menghemat biaya produksi dan mengoptimalkan jarak pengangkutan material selama proses produksi berlangsung. Permasalahan yang ditemukan di lokasi penelitian yaitu letak stasiun kerja tidak teratur dan tidak sesuai dengan pergerakan aliran material sehingga aliran proses produksi menjadi tidak lancar dan menghabiskan waktu proses produksi yang lama.

Dari permasalahan di atas maka peneliti melakukan pendekatan tata letak fasilitas untuk mengurangi biaya material handling dan memperpendek jarak perpindahan material yaitu dengan metode algoritma CRAFT. Material handling memiliki pengaruh terhadap operasi dan perencanaan fasilitas yang akan diimplementasikan atau dilakukan penataan ulang (Rochman, dkk 2009). Algoritma CRAFT membangun tata letak baru dengan input dari tata letak awal yang ditingkatkan dengan beberapa kali iterasi hingga didapatkan tata letak akhir yang optimal, hasil dari tata letak optimal sangat bergantung pada input tata letak awal. Metode kualitatif yang digunakan dalam penelitian ini adalah peta relasi aktivitas (ARC). Menurut Wignjosoebroto (2009), peta hubungan aktivitas merupakan teknik sederhana dalam perencanaan tata letak fasilitas atau departemen berdasarkan derajat aktivitas hubungan. Peta hubungan aktivitas sering kali diekspresikan dalam penilaian "kualitatif" dan cenderung didasarkan pada pertimbangan yang bersifat objektif. Dari peta relasi aktivitas (ARC) akan didapat layout baru CV.XYZ yang berasal dari keterkaitan kedekatan dengan aktivitas yang nanti akan dibandingkan dengan metode awal dan hasil dari metode CRAFT. Untuk mengevaluasi performansi perbaikan performansi sistem disimulasikan menggunakan software simulasi Promodel 7.5. Schriber (1987) mengatakan bahwa simulasi berkaitan dengan pemodelan suatu proses atau sistem dengan cara tertentu sehingga model tersebut meniru respon sistem yang sebenarnya terhadap suatu kejadian yang terjadi sesuai dengan waktu. Simulasi ini dilakukan dengan alasan jika kita melakukan eksperimen secara langsung dengan menerapkan model baru pada layout sistem yang sebenarnya tentunya akan mengganggu sistem yang sedang berjalan dan menghabiskan banyak biaya.

Penelitian mengenai perancangan tata letak fasilitas dengan algoritma CRAFT sudah pernah dilakukan sebelumnya oleh Darmawan dkk tahun 2015 yang melakukan penelitian pada pabrik sepatu dan membandingkan layout awal dengan layout usulan berdasarkan metode algoritma CRAFT serta membandingkan layout berdasarkan total momen perpindahan dan benefit cost ratio. Sedangkan untuk penelitian sebelumnya yang melakukan perancangan tata letak fasilitas produksi dengan metode CRAFT dan simulasi di industri manufaktur telah dilakukan oleh Ariestyadi ddk 2011 dan Sri Lestari. Perbedaan antara penelitian ini dengan yang lainnya adalah lokasi dan objek penelitian, lama waktu pengambilan data serta penggunaan simulasi dan adanya penambahan metode ARC sebagai pembanding antara layout awal dengan layout susulan hasil metode CRAFT.

\section{Methods}

\subsection{Pengumpulan Data}

Data yang dikumpulkan pada penelitian ini berupa data primer yang diperoleh langsung dari observasi di CV. XYZ. Data yang berhasil dikumpulkan adalah data proses produksi, transfer data entitas antar lokasi, tata letak proses produksi, jadwal kedatangan bahan baku, jadwal kerja harian pekerja, biaya produksi dan biaya perpindahan pekerja, jarak antar pekerjaan dan jarak antar stasiun kerja. Pengamatan dan pengumpulan data langsung dilakukan di wilayah Cebongan, Sleman Yogyakarta untuk melihat produksi kerajinan bamboo yaitu kursi selama satu bulan. 


\subsection{Pengolahan Data}

Pengolahan data pada penelitian ini dilakukan berdasarkan tahap-tahap di bawah ini:

1. Tentukan koordinat jarak dari layout awal yang dibuat di Ms. Exel serta tentukan total biaya material handling pekerja.

2. Hitung biaya material handling berdasarkan metode CRAFT dengan bantuan software WinQSB kemudian akan didapatkan layout yang optimal.

3. Menyusun Activity Relationship Chart (ARC) dengan memperhatikan hubungan antar kegiatan setiap stasiun kerja, setelah itu akan didapat tata letak baru berdasarkan metode ARC.

4. Setelah mendapatkan layout baru dengan metode CRAFT dan ARC maka Langkah selanjutnya adalah melakukan simulasi dengan bantuan software Promodel 7.5.

5. Melakukan analisis hasil simulasi.

\section{Hasil dan Pembahasan}

\subsection{Pengumpulan Data}

Proses pengumpulan data pada CV. XYZ dilakukan untuk melihat hasil produksi produk kursi selama satu bulan. Data yang dikumpulkan berupa data layout awal yaitu jarak antar departemen, data frekuensi perpindahan, data ongkos material handling dll. Proses pengumpulan data dilakukan langsung dengan wawancara dan pengamatan di lokasi penelitian. Berikut beberapa data yang berhasil dikumpulkan di lokasi penelitian.

\begin{tabular}{|c|c|c|c|c|c|c|c|c|c|c|c|c|c|c|c|c|}
\hline & 1 & 2 & 2 & 3 & 4 & 5 & 6 & 7 & & 8 & 9 & 10 & & & $\begin{array}{ll}13 & 1\end{array}$ & 1 \\
\hline 1 & & A & A & A & A & A & \pm & $B$ & $B$ & $B$ & $K$ & $\mathrm{~K}$ & $K$ & $\mathrm{~K}$ & $K$ & $K$ \\
\hline 2 & & A & A & A & A & A & 4 & $B$ & $B$ & B & K & K & K & K & K & K \\
\hline 3 & & A & A & A & A & A & 4 & $B$ & $B$ & $B$ & $\mathrm{~K}$ & $\mathrm{~K}$ & $\mathrm{~K}$ & $\mathrm{~K}$ & $\mathrm{~K}$ & $\mathrm{~K}$ \\
\hline 4 & & A & A & A & A & A & & $B$ & $B$ & $B$ & $\mathrm{~K}$ & $\mathrm{~K}$ & $\mathrm{~K}$ & $\mathrm{~K}$ & $\mathrm{~K}$ & $\mathrm{~K}$ \\
\hline $5 A$ & & $A$ & A & A & A & A & & $B$ & $B$ & $B$ & K & $\mathrm{K}$ & $\mathrm{K}$ & $\mathrm{K}$ & $\mathrm{K}$ & $\mathrm{K}$ \\
\hline $6 C$ & & C & C & C & D & D & 5 & E & E & $E$ & E & $E$ & $F$ & $F$ & $F$ & $F$ \\
\hline $7 \mathrm{C}$ & & C & C & C & $D$ & D & 2 & $\mathrm{E}$ & $\mathrm{E}$ & $\mathrm{E}$ & $\mathrm{E}$ & $E$ & $\mathrm{~F}$ & $\mathrm{~F}$ & $F$ & $F$ \\
\hline $8 \mathrm{C}$ & & C & C & C & & & & E & E & $E$ & E & E & $F$ & $F$ & $F$ & $F$ \\
\hline $9 \mathrm{H}$ & & $\mathrm{H}$ & $\mathrm{H}$ & 1 & 1 & & & J & $\mathrm{J}$ & $\mathrm{J}$ & $\mathrm{J}$ & $\mathrm{J}$ & $\mathrm{G}$ & $\mathrm{G}$ & $\mathrm{G}$ & G \\
\hline $10 \mathrm{H}$ & & $\mathrm{H}$ & $\mathrm{H}$ & 1 & 1 & I & & J & J & J & J & J & G & G & G & G \\
\hline
\end{tabular}

Gambar 1. Layout Awal

Tabel 1. Keterangan Lokasi

\begin{tabular}{|c|c|c|}
\hline Initial & Keterangan & Koordinat \\
\hline A & Pencucian Bambu & $(1,1)-(5,6)$ \\
\hline B & Gudang Bambu & $(1,7)-(5,9)$ \\
\hline C & Buffer C & $(6,1)-(8,4)$ \\
\hline D & Buffer WIP & $(6,5)-(6,6)$ \\
\hline E & Pemotongan Bambu & $(6,7)-(6,11)$ \\
\hline F & Kerangka & $(6,12)-(8,15)$ \\
\hline G & Finishing & $(9,12)-(10,15)$ \\
\hline H & Gudang Rotan & $(9,1)-(10,3)$ \\
\hline I & Pemotongan Rotan & $(9,4)-(10,6)$ \\
\hline J & Perakitan & $(9,7)-(10,11)$ \\
\hline K & Gudang Jadi & $(1,10)-(5,15)$ \\
\hline
\end{tabular}


Tabel 2. Jarak Antar Departemen

\begin{tabular}{|c|c|c|c|}
\hline $\begin{array}{c}\text { Initial } \\
\text { Workstation }\end{array}$ & $\begin{array}{c}\text { Destination } \\
\text { Workstation }\end{array}$ & $\begin{array}{c}\text { Distance among } \\
\text { department }(\mathrm{m})\end{array}$ & $\begin{array}{c}\text { Ongkos Material } \\
\text { Handling (\$) }\end{array}$ \\
\hline A & C & 4.5 & 1.735 \\
\hline B & A & 5.5 & 1.735 \\
\hline C & E & 4.5 & 1.735 \\
\hline D & F & 3.5 & 1.735 \\
\hline E & D & 3 & 1.735 \\
\hline F & J & 6.5 & 1.735 \\
\hline J & B & 7.3 & 1.735 \\
\hline H & I & 3 & 1.735 \\
\hline I & J & 5 & 1.735 \\
\hline J & G & 3.5 & 1.735 \\
\hline G & K & 6.5 & 1.735 \\
\hline K & H & 13.5 & 1.735 \\
\hline
\end{tabular}

\subsection{Pengolahan Data}

Langkah selanjutnya setelah data terkumpul adalah melakukan pengolahan data. Data pada Tabel 2 adalah data masukan untuk pengolahan data di software WinQSB. Identifikasi masalah pada tata letak fasilitas pada CV.XYZ merupakan standalone spacing area yang dilihat berdasarkan alur prosesnya. Hal ini dilakukan untuk mengetahui seberapa besar persentase biaya material handling sebelum dan sesudah adanya usulan perbaikan tata letak fasilitas pada CV. XYZ. Perancangan layout dengan metode CRAFT dengan bantuan software WinQSB ini membutuhkan input data seperti jarak antar departemen dan biaya material handling per satuan jam.

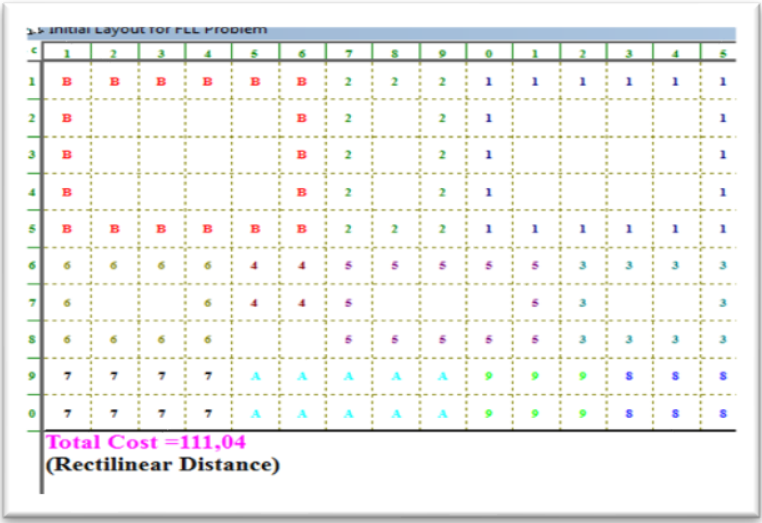

Gambar 2. Initial Layout Using WinQSB

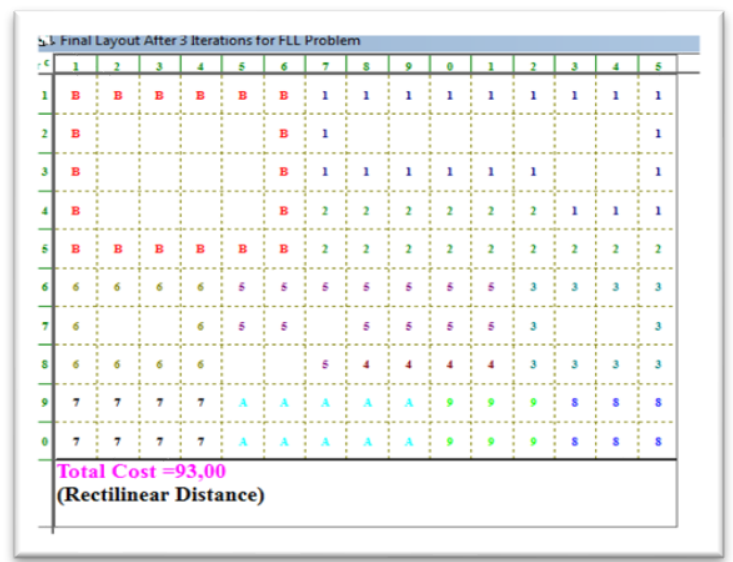

Gambar 3. Optimal Layout Using WinQSB

Berdasarkan software WinQSB, biaya material handling layout awal yaitu \$ 111,04 sedangkan setelah di iterasi hingga mencapai layout optimal maka biaya material handling optimum menjadi $\$ 93,00$. Sehingga dapat disimpulkan dengan metode CRAFT biaya material handling yang lebih murah. Untuk dapat membandingkan biaya material handling dengan metode CRAFT, pada penelitian ini akan melakukan perbandingan dengan metode Activity Relationship Chart (ARC) untuk mencari tahu hubungan antara keterkaitan atau keeratan stasiun kerja dengan membuat ARC yang memperlihatkan penempatan masing-masing stasiun kerja berdasarkan hubungan kedekatan alur proses produksi. Gambar di bawah ini merupakan penentuan lokasi yang didekatkan berdasarkan hubungan aktivitas antar lokasi tersebut. 


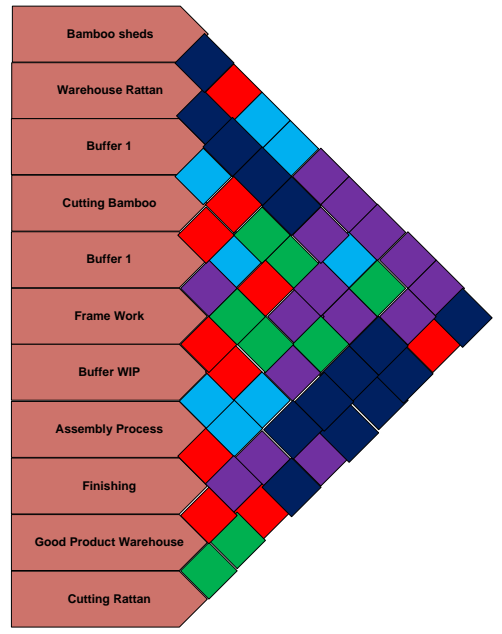

\section{ACTIVITY RELATIONSHIP CHART \\ (ARC)}

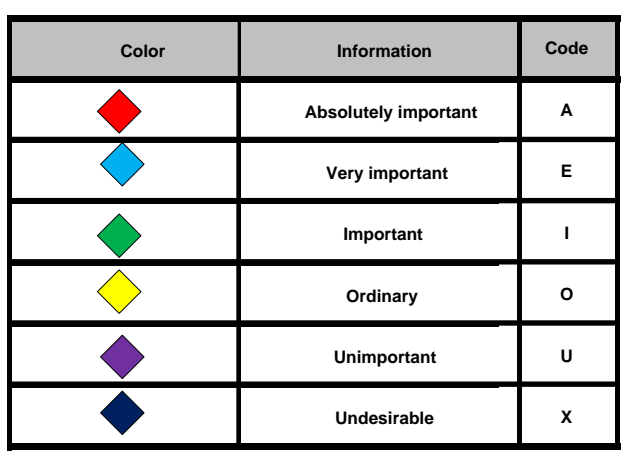

Gambar 4. ARC

Berdasarkan Gambar 4 diketahui bahwa beberapa departemen didekatkan berdasarkan hubungan keterkaitan antara setiap stasiun kerja. Setelah mendapatkan layout baru berdasarkan hasil ARC maka langkah selanjutnya adalah melakukan simulasi untuk membandingkan performansi tata letak yang berasal dari metode CRAFT dan juga ARC. Berikut adalah gambar model metode ARC and CRAFT dengan software simulasi Promodel 7.5.

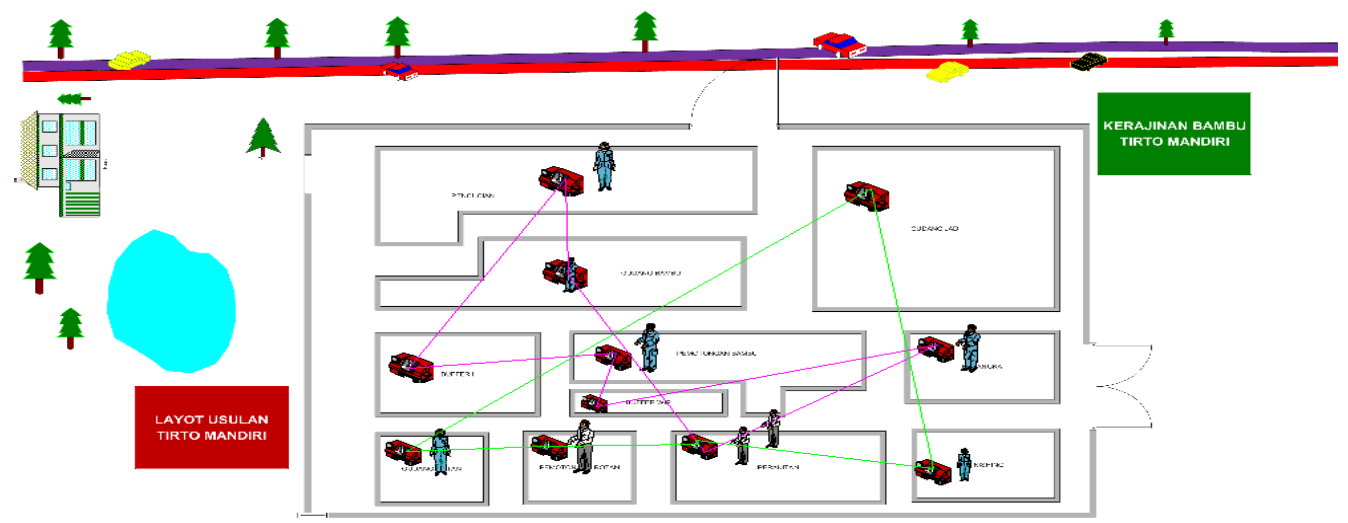

Gambar 5. Layout Berdasarkan hasil ARC

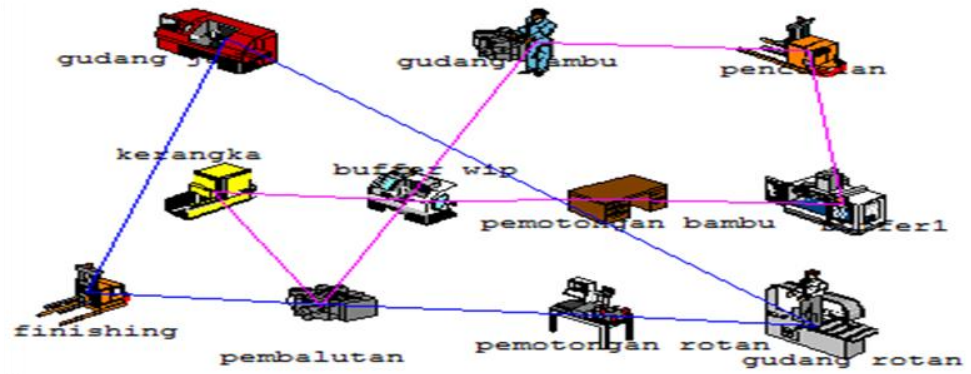

Gambar 6. Layout Berdasarkan CRAFT 
Tabel 3. Perbandingan CRAFT, ARC, Layout Awal Dengan Simulasi

\begin{tabular}{|c|c|c|c|c|}
\hline Metode & $\begin{array}{c}\text { Total } \\
\text { Entris }\end{array}$ & $\begin{array}{c}\text { Total Cost dollar Entitas } \\
\text { “Kursi Jadi” }\end{array}$ & $\begin{array}{c}\text { Total \% Utilization } \\
\text { Seluruh Operator }\end{array}$ & $\begin{array}{c}\text { \%Pengurangan } \\
\text { Biaya Material } \\
\text { Handling }\end{array}$ \\
\hline CRAFT & 21 & 2149.85 & 56,44 & $12,55 \%$ \\
\hline ARC & 20 & 2318,68 & 59,69 & $5,69 \%$ \\
\hline Layout Awal & 20 & 2458.75 & 21,51 & - \\
\hline
\end{tabular}

Tabel di atas merupakan perbandingan hasil simulasi pendekatan antara model awal, metode CRAFT, dan ARC. Unsur-unsur yang dibandingkan adalah total entry yaitu jumlah produk yang diproduksi selama satu bulan, material handling operator, material handling, kinerja operator dan total biaya produksi jok jadi entitas. Jumlah entri dalam metode CRAFT terbesar dibandingkan layout awal dan model ARC, karena tata letak metode CRAFT merupakan tata letak optimal yang didapat dengan bantuan software. Dikarenakan metode ARC hanya merupakan asumsi yang bersifat subjektif sehingga tata letak suatu metode CRAFT dapat menghasilkan total entries yang lebih banyak. Sedangkan pada layout awal, model produksi belum diatur, sehingga perpindahan operator material handling dari satu stasiun kerja ke stasiun kerja yang lain membutuhkan waktu yang cukup lama.

Sedangkan untuk utilitas operator, metode ARC memiliki total persentase tertinggi yaitu 59,69\% dan memiliki selisih yang kecil dengan metode CRAFT. Hal ini dikarenakan ARC fokus pada alur proses produksi sehingga suatu lokasi memiliki keterkaitan karena proses material handling akan lebih dekat. Mengenai kinerja operator penanganan material pada setiap lokasi metode utilitasnya terbilang kecil. Pada metode CRAFT diperoleh relayout adalah reorganisasi layout produksi yang paling optimal, sehingga tidak ada ruang atau area stasiun kerja kosong.

Hasil penurun biaya material handling yang diperoleh dari kedua metode tersebut tidak terlalu signifikan lebih dari $12 \%$ dari tata letak awal. Hal tersebut disebabkan oleh kecilnya sistem produksi sehingga perawatan apapun yang dilakukan hasilnya tidak jauh berbeda. Waktu proses produksi dalam sistem pembuatan kursi yang lebih lama dari waktu proses material handling menyebabkan kegunaan material handling operator tidak begitu menonjol. Pada analisis di atas, metode CRAFT dan ARC lebih baik daripada model awal, tetapi masingmasing memiliki kelebihan dan kekurangan. Peneliti menyarankan untuk menggunakan model CRAFT karena memiliki keunggulan lebih dari pada ARC yaitu dapat mengurangi biaya material handling paling banyak baik menggunakan software WinQSB ataupun saat disimulasikan.

\section{Kesimpulan dan Saran}

\subsection{Kesimpulan}

Dari analisis yang telah dilakukan terhadap permasalahan di lantai produksi CV.XYZ dapat disimpulkan bahwa:

1. Perancangan tata letak fasilitas dapat mengurangi biaya material handling terbesar adalah desain tata letak fasilitas dengan metode CRAFT, biaya material handling pada CV. XYZ dapat dikurangi sebesar $16,25 \%$ hal tersebut dilakukan dengan mengubah posisi stasiun kerja Bamboo Shed dan Buffer WIP.

2. Berdasarkan hasil simulasi yang diperoleh, bahwa dengan menggunakan metode CRAFT belum sepenuhnya memberikan solusi yang terbaik. Namun layout usulan dengan metode CRAFT lebih baik dibandingkan dengan layout usulan metode ARC ataupun inisial layout. Ada perbedaan antara pengurangan biaya material handling yang didapatkan melalui perhitungan software WinQSB dibandingkan hasil simulasi yaitu $16,25 \%$ berbanding $12,55 \%$.

\subsection{Saran}

Saran yang diberikan oleh peneliti untuk penelitian ini adalah akan lebih baik jika dilakukan penelitian lanjutan mengenai beberapa aspek lain yang dapat mendukung penerapan perbaikan desain tata letak fasilitas ini, seperti aspek teknis, aspek ergonomi, dan aspek-aspek lain sebagainya. Sehingga dalam perancangan tata letak perbaikan fasilitas bisa benar-benar lebih efektif dan efisien. Sedangkan bagi perusahaan perlu memperhatikan tata letak fasilitas pabrik dengan baik karena dapat membawa keuntungan bagi perusahaan. Kemudian untuk ongkos material handling dapat dikurangi, perusahaan mempekerjakan satu orang sebagai operator bergerak, karena berdasarkan simulasi tingkat utilitas operator bergerak sangat rendah. 


\section{Daftar Pustaka}

1. Anthara, I.M.A., (2005). Usulan Perbaikan Tata Letak Produksi Dengan Metode CRAFT Untuk Meminimasi Ongkos Material Handling (Studi Kasus di CV.Karya Mekar Bandung), Jurnal Majalah IImiah UNIKOM, 8(1), 107-118.

2. Ardhianto, A., (2008). Usulan Perbaikan Tata Letak Fasilitas Pada Usaha Kecil Menengah Konveksi Adios. Universitas Gunadarma. Jakarta Timur.

3. Ariestyadi, R., dkk., (2011). Perancangan dan Simulasi Tata Letak Fasilitas Pabrik Dengan Menggunakan Algoritma CRAFT di PT XYZ. Proceedings Seminar Nasional Teknik Industri \& Kongres BKSTI VI, 1-37.

4. Darmawan, R.I., dkk., (2015). Perbaikan Tata Letak Fasilitas Produksi Menggunakan Algoritma CRAFT. Proceeding Seminar Sistem Produksi XI.

5. Hadi, E., (2008). Usulan Perbaikan Tata Letak Fasilitas Pada Industri Sandal.Universitas Gunadarma.Depok.

6. Lestari, S., (2014). Analisa Tata Letak Pabrik Untuk Meminimalisasi Material Handling Pada Pabrik Sheet Metal Dengan Software Promodel. Jurnal Teknik 3(1), 106-113.

7. Maria, A., (1997). Introduction To Modeling And Simulation. Proceeding of the $29^{\text {th }}$ Winter Simulation Conference. USA, 7-13.

8. Purnomo, H., (2004), Perencanaan dan Perancangan Fasilitas, Graha Ilmu, Yogyakarta.

9. Rochman, T., dkk, (2010). Peningkatan Produktivitas Kerja Operator Melalui Perbaikan Alat Material Handling Dengan Pendekatan Ergonomi. Performa, 9(1), 1-10.

10.Sahroni. 2003. Perencanaan Ulang Tata Letak Fasilitas Produksi Dengan Metode Algoritma CRAFT. Optimum. Vol.4 No.1. Halaman 72-82.

11.Savsar, M., dan Aldehaim, A. (2020). Analysis and Improvement of Facility Layout in Furniture Factory: A Case Application. Proceedings of International Conference on Industrial Engineering and Operations Management, 436-447.

12. Wignjosoebroto, S., (2020). Tata Letak Pabrik dan Pemindahan Bahan. Edisi Ketiga. Cetakan Kedua. Prima Printing. Surabaya. 